UNIO - EU Law Journal. Vol. 5, No. 1, January 2019, pp 76-84.

®2019 Centre of Studies in European Union Law

School of Law - University of Minho

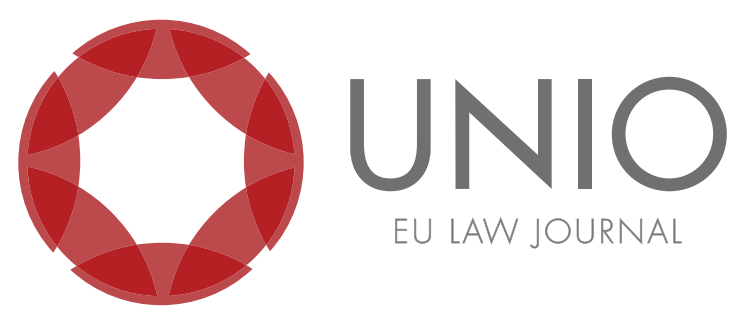

\title{
E-justice and international land conveyancing
}

Afonso Patrão*

ABSTRACT: This paper explores the obstacles regarding cross-border transactions on immoveable property within the European Union. The existence of obstacles to the exercise of the freedom of movement of capitals, such as travel costs to the country where the property is located and finding a notary there, may even lead the parties not to enter in those contracts. E-justice solutions are being created to solve such situations and this paper reflects if they are enough to overcome the difficulties and rectify current deficiencies. It concludes by examining the tendency of solving the difficulties of international cooperation between non-judicial authorities through e-Justice tools.

KEYWORDS:E-justice - freedom of movement of capital - land registrar-notary-international land conveyancing.

\footnotetext{
* Professor at the Faculty of Law of the University of Coimbra.
} 


\section{The problem}

In cross-border transactions on immoveable property within the European Union, guaranteed by the basic freedoms (specially freedom of movement of capital), a major obstacle exists: because Member States often establish preventive systems on conveyancing - obliging the contract to be concluded before a public notary or other authority, ruling out causes of invalidity, and submitting the production of all legal effects to a Land Registrar's decision -, contracting in a different Member State of the situation of the plot of land is a difficult task.

Consider an example: if two European citizens from the Netherlands wish to benefit from the freedom of movement of capital by transferring property in Spain, the possibility of conveyancing in the Netherlands (or in another different country from the one of the property) will present significant challenges. The obstacles are so many that some writers take the conclusion of, from a practical point of view, it is mandatory to conclude the contract in the country where the situation of the plot is regulated. This circumstance is a barrier to the exercise of the European freedoms: it makes it mandatory for the individuals to travel to the country where the property is located; it prevents the possibility to draw up the deed before a notary known to the parties, in who they trust; and probably, it forces the notarial act to be written in a foreign language, unknown to the parties. Thus, additional costs are created and uncertainty on the effectiveness of the transaction arises. Possibly, the consideration of all costs and risks may even lead the parties not to enter in such contracts.

There are several reasons for this status quo.

On the one hand, some Member States establish the obligation of contracts regarding immoveable property to be concluded before a public Notary of the country where the immovable is situated. ${ }^{1}$

\footnotetext{
${ }^{1}$ This is the case of France regarding mortgages (Article 2417 Code Civil - Les contrats passés en pays étranger ne peuvent donner d'bypothèque sur les biens de France, s'il n'y a des dispositions contraires à ce principe dans les lois politiques ou dans les traités") and the case of the Netherlands [Article 3(31) Burgerlijk Wetboek - Waar een wetsbepaling die betrekking heeft op registergoederen, een notariële akte of een notariële verklaring voorschrijft, is een akte of verklaring van een Nederlandse notaris vereist']. These legal rules are, obviously, difficult to harmonise with European rules on the freedom to provide services, of which Dutch authors are aware - vide A. V. M. Struycken, «Les conséquences de l'intégration européenne sur le développement du droit international privé,» Recueil des Cours de l'Académie de Droit International 1992-I, Tomo 232 (1992): 318. With regard to the French rule, writers criticise it sharply - cf. Pierre Callé, «L'acte authentique établi à l'étranger - Validité et exécution en France,» Revue Critique de Droit International Privé, vol. 94, No. 3 (2005): 391; Michel Cabrillac and Christian Mouly, Droit des Sûretés (Paris: Éditions Litec, 1999), 627; André Weiss, Manuel de Droit International Privé (Paris: Sirey, 1905), 539; Dominique Bureau and Horatia Muir Watt, Droit international privé, in Partie spéciale (Paris: Presses Universitaires de France, 2010), 51; Charalambos Pamboukis, L'Acte Public Étranger en Droit International Privé (Paris: LGDJ, 1993), 232; Georges A. L. Droz, «Problèmes soulevés par l'établissement, en Angleterre ou aux Etats-Unis, d'un mandat d'hypothéquer un immeuble français,» in Mélanges en hommage à André Breton et Fernand Derrida (Paris: Dalloz, 1991), 93; Marcel Planiol and Georges Ripert, Traité Pratique de Droit Civil Français (Paris: Librairie Générale de Droit et de Jurisprudence, 1927), 427; Tito Ballarino, "Norme di Applicazione Necessaria e Forma degli Atti," Rivista di Diritto Internazionale Privato e Processuale Anno III (1967): 723. A similar effect may be sustained by the system of transferral of rights in rem, which is unanimously given to lex rei sitae, if the country of situation of the plot establishes the necessity, besides the contract of sale, of an abstract contract of transferal (the case of Germany, because the expression "jeder Notar" of \$925 BGB is interpreted in conferring powers only to Notaries established in Germany - ("kann aber nicht gefolgert werden, dass auch die Zuständigkeit eines ausländischen Notars gegeben sei") - Ruling of Oberlandesgericht of Cologne, 29 of November of 1971, Der Deutsche Rechtspfleger, No. 4, 1972, pp. 134; Kanzleiter, "\$925," in Münchener Kommentar zum Bürgerlichen Gesetə̧buch, ed. Roland Rixecker and Franz Jürgen Säcker (München: Beck, 2013), No. 14, nota 40; Reinhold Geimer, "Eintragungsfähigkeit einer von einem deutschen Notar
} 
On the other hand, even if there is a legal possibility of conveyancing in a different country of the situation of the property, there are obstacles concerning the circulation of the public document containing the contract, not only with regard to its formal acceptance (an issue which has been out of the European acts on civil judiciary cooperation) ${ }^{2}$ but also - even if there are no doubts on the authenticity of the foreign document as instrumentum - to the recognition of the negotium (formal equivalence to the documents possibly demanded by lex situs; substantive validity of the contract, probably mentioning legal institutes different from the ones of lex rei sitae). ${ }^{3}$

Thirdly, even assuming all mentioned difficulties do not prevent the parties from entering into such a contract, the pragmatic possibility of conveyancing is often compromised. In fact, the law of many Member States gives public responsibilities to Notaries (or similar authorities) when conveyancing immoveable property: the duty to collect taxes; the obligation of verifying public licences as a prerequisite of the transaction; the certification in Land Registry of the seller's property rights; the obligation to give notice to police authorities of the suspicion of money laundering or terrorist financing; the obligation to coordinate the title with geometric registry; or even the duty of receiving the price from the buyer and transfering it to the seller after the confirmation of the transaction success. ${ }^{4}$ In fact, these duties are often impossible

errichteten Kaufvertragsurkunde im spanischen Eigentumsregister," IPRax — Praxis des Internationalen Privat und Verfahrensrechts No. 5 (2013): 481.

${ }^{2}$ In fact, the issues concerning the acceptance and recognition of public documents are less treated than judiciary decisions, which can be a surprise, because of the consensual nature of the former. Cfr. Georges A. L. Droz, La compétence judiciaire et l'effet des jugements dans la Communauté économique européenne selon la convention de Bruxelles du 27 septembre 1968 (Paris: Dalloz, 1972), No. 605; José Carlos Fernández Rozas and Sixto Sánchez Lorenzo, Curso de Derecho Internacional Privado (Madrid: Editorial Civitas, 1996), 98;. Jonathan Fitchen, "«Recognition», Acceptance and Enforcement of Authentic Instruments in the Succession Regulation," Journal of Private International Law, vol. 8, No. 2 (2012): 329; Pierre Callé, L'acte public en droit international privé (Paris: Economica, 2004), 2, and «L'acte authentique....» 380; Marie Goré, «L'Acte Authentique en Droit International Privé,» Travaux du Comité Français de Droit International Privé (1998-1999): 23; Charalambos Pamboukis, «Les actes publics et la méthode de reconnaissance,» in La Reconnaissance des situations en droit international privé, ed. Paul Lagarde (Paris: Pedone, 2013), 133; Richard Crône, «La réception d'un acte authentique étranger en France,» in Mélanges en l'Honneur de Mariel Revillard - Liber amicorum (Paris: Defrénois, 2007), 77 ("la doctrine internationaliste classique ne s'est guère préoccupée de la circulation et de l'exécution des actes authentiques»); Michael Bogdan, «Do Swedish Civil Status Records Qualify to be Recognized in the Other EU Member States?,» in Liber Amicorum Ole Lando, ed. Michael Joachim Bonell, Marie-Louise Holle, and Peter Arnt Nielsen (Copenhaga: DJØF, 2012), 60 ("In contrast to most court judgments, the recognition in EU remember state of the contents of civil status records of another member state is not generally regulated by EU legislation"). After the adoption of the European Succession Regulation (EU 650/2012), however, the debate on this area has been increased, because of the preponderant necessity of finding solutions in that domain (cfr. Cyril Nourissat et al., "Pour la reconnaissance des actes authentiques au sein de l'espace de liberté, de sécurité et de justice," Petites Affiches No. 68, 4 April 2012 (2012), chapter III; Paul Terner, "Perspectives of a European Law of Succession," Maastricht Journal of European and Comparative Law, vol. 14, No. 2 (2007): p. 166).

${ }^{3}$ On these difficulties, vide Afonso Patrão, Autonomia conflitual na hipoteca e reforço da cooperação internacional: removendo obstáculos ao mercado europeu de garantias imobiliárias (Lisboa: Livros Horizonte, 2017), 307ss. On the distinction between negotium and instrumentum, cfr. Georges A. L. Droz, «L'Activité Notariale Internationale,» Recueil des Cours de l'Académie de Droit International, Tomo 280 (1999): 28.

${ }^{4}$ Cf. the examples of French law (Mariel Revillard, Droit International Privé et Communautaire: Pratique Notariale (Paris: Defrénois, 2006), 480 and Spanish Law (Luis Javier Arrieta Sevilla, "La inscribilidad de escrituras públicas extranjeras a la luz de la primera doctrina hipotecaria," in El documento público extranjero en España y en la Unión Europea. Estudios sobre las características y efectos del documento público, ed. Maria Font i Mas (Barcelona: Bosch, 2014), 424ff. Under Portuguese Law, vide the obligations of communication to fiscal authorities (art. 57. ${ }^{\circ} \mathrm{CNot}$.); the duty to harmonise the contract with Fiscal 
to fulfil by foreign officials, making the contracts abroad legally allowed but pragmatically impossible. ${ }^{5}$

Finally, even supposing it was feasible for a foreign notary to conveyance property abroad, the access from a different Member State to necessary information on the plot is purely unachievable: many Member States do not allow online registration or online access to public registry by foreign conveyancers, demanding national IDs of the supplicant ${ }^{6}$; others do not adopt a free access Land Registration system, demanding evidence of a serious interest - increasing difficulties for foreign conveyancers; ${ }^{7}$ and in the cases where the accession is possible, a foreign public notary may not be able to fully understand the legal institutes inscribed or the language of Registration data. ${ }^{8}$ Furthermore, there are disparities between the Land Registries from one Member State to the next - regarding title and document systems; transcription and inscription systems; plot

and Land registries (art. 58. ${ }^{\circ} \mathrm{CNot}$ ); the burden of demanding the plot is registered in the name of the seller (arts. 9. ${ }^{\circ}$ CRPred. e 54. ${ }^{\circ} \mathrm{CNot}$ ); the responsibility of promoting registration of the asset (al. b) do n. ${ }^{\circ} 1$ do art. 8. ${ }^{\circ}$-B CRPred.); the onus of demanding the payment of taxes as a prerequisite of the contract (art. 49. ${ }^{\circ}$ do Código do IMT); the obligation of verifying the handover of the house's technical data (art. 9. ${ }^{\circ}$ do Decreto-Lei n. ${ }^{\circ}$ 68/2004, de 25 de Março); the responsibility of ascertaining the existence and validity of the licence for using the plot (art. 1. ${ }^{\circ}$ do Decreto-Lei n. ${ }^{\circ}$ 281/99, de 26 de Julho); and the burden of certifying the energy certificate of the building (art. $5 .^{\circ}$ do Decreto-Lei n. ${ }^{\circ}$ 118/2013, de 20 de Agosto).

${ }^{5}$ Cf. Javier Carrascosa González, "Derechos Reales (Capítulo XXIX),” in Derecho Internacional Privado, ed. Alfonso Luis Calvo Caravaca and Javier Carrascosa González (Granada: Ed. Comares, 2011), 906 ("El notario extranjero no puede realizar el mismo control que lleva a cabo un Notario español porque no es un funcionario publico español y no dispone de medios técnicos ni legales para practicar el control que sí realiza el Notario español: un Notario extranjero no puede recabar datos del Ministerio de Hacienda español, por ejemplo, ni está obligado a comunicar movimientos sospechosos de capitales a la Hacienda española, como sí lo está el Notario español”); Enrique Brancós Núñez, "El europeísmo equivocado de la sentencia 391/06, de 22 noviembre de 2006, de la Audiencia Provincial de Santa Cruz de Tenerife, Sección cuarta," La Notaría n. ${ }^{\circ} 37-38$ (2007) n. ${ }^{\circ}$ 37-38 (2007: 124. Against, cf. Álvaro Núñez Iglesias, «El préstamo hipotecario transfronterizo: la eurohipoteca,» Boletín del Centro de Estudios Registrales de Cataluña n. 93 (2001): 371, footnote n. 9.

${ }^{6}$ Mortgage Funding Expert Group, Report of 22 December 2006, (Bruxelas: Comissão Europeia, 2006), 18, http:/ / ec.europa.eu/internal_market: "In six of the Member States surveyed (Denmark, Germany, Italy, Hungary, Portugal and Sweden) mortgage registers are nor accessible cross-border. In some Member States, this arises from legislation or standards imposed by authorities, whereas in other Member States, it is simply a technical question; [...] on-line registration is only accessible in half of the Member States"). Also, Comissão Europeia, Livro Verde "O crédito hipotecário na UE" - COM(2005)327 Final, (Bruxelas, 2005), p. 15; Grupo-Fórum relativo ao crédito hipotecário, The Integration of the EU Mortgage Credit Markets - Report of the Forum Group on Mortgage Credit (Bruxelas: Comissão Europeia, 2004), 28-29, http:/ / ec.europa.eu/internal_market/ finservices-retail/docs/home-loans/2004-report-integration_en.pdf; Hendrik Ploeger and Bastiaan van Loenen, Response to the Green Paper on Mortgage Credit in the EU, (Delft2005), 1, http://ec.europa.eu/ internal_market/finservices-retail/docs/home-loans/comments/priv-nl_ploeger_vanloenen-en.pdf.

${ }^{7}$ Cfr. Antonio Pau Pedrón, "The Register as an Instrument of Security in Property Transactions," in Land Law in Comparative Perspective, ed. Elena Sánchez Jordán and Antonio Gambaro (Haia: Kluwer Law International, 2002), 92.

${ }^{8}$ Hendrik Ploeger and Bastiaan van Loenen, "EULIS - At the Beginning of the Road to Harmonization of Land Registry in Europe," European Review of Private Law, vol. 12, No. 3 (2004): 381, and "Harmonization of Land Registry in Europe," TS18 - Comparative Aspects of Land Administration Systems, From Pharaohs to Geoinformatics (2005), 3, http://www.fig.net/pub/cairo/papers/ts_18/ts18_02_ploeger_vanloenen. pdf, exemplifying with the case of an English citizen trying to buy a property in the Netherlands: even if he can access the Dutch Kadaster, all he will find out is that the seller is "erfpachter" and municipal authorities are "eigenaar", without understanding the meaning of each legal figure. Vide "The European Real Estate Market - Transparency, Security and Certainty through registration by EuroTitle," in The Future of European Property Law, ed. Sjef van Erp, Arthur Salomons, and Bram Akkermans (Munique: Sellier European Law Publishers, 2012), 186, on the similar scenario within French Land Registry. 
organised or person organised -, the foreign conveyancer has no hint on the path to follow. ${ }^{9}$

Thus, the parties' option to conclude the contract in a Member State other than the one of the situation of the property is risky: the public notary may not know or may not be able to comply with all the requirements of lex rei sitae for the transaction. In consequence, there is a chance of not effectively transferring the property, compelling the parties to contract in the country of situation of the immoveable property bearing the uncertainty given by a Notarial act written in a language the parties do not understand ${ }^{10}$ : "the practical solution is that a local advisor is hired".

This problem was acknowledged by the European Parliament, who stated it was not legally forbidden to contract abroad but the contracts were often unrecognised in the country of the property. ${ }^{12}$

\section{European projects: e-Justice and international conveyancing}

Being aware of the problem, the European Union is funding projects using e-Justice as a means of overcoming the difficulties and specifically mentioned them in the Green Book on Mortgage Credit, stressing its commitment. ${ }^{13}$ In this presentation, we will focus three on them: CROBECO, EU-Fides and IMOLA.

\section{CROBECO - Cross Border Electronic Conveyancing}

ELRA (European Land Registry Association) started developing CROBECO (Cross-Border Electronic Conveyancing) intended to simplify international contracts on immoveable property by enhancing cooperation between Land Registrars of different Member States.

\footnotetext{
${ }^{9}$ Elena Sánchez Jordán, "Garantías sobre Bienes Inmuebles: La Eurohipoteca," in Derecho Privado Europeo, ed. Sergio Cámara Lapuente (Madrid: Editorial Colex, 2003), 996-997, e "La Eurohipoteca," in Estudios Jurídicos en Homenaje al Profesor Luis Diez-Picazo, ed. Antonio Cabanillas Sánchez (Madrid: Thomson - Civitas, 2003), 4288; Christoph Schmid and Christian Hertel, Real Property Law and Procedure in the European Union - General Report (Florença: European University Institute; European Private Law Forum; Deutsches Notarinstitut, 2005), 29, http://www.eui.eu/Documents/DepartmentsCentres/ Law/ResearchTeaching/ResearchThemes/EuropeanPrivateLaw/RealPropertyProject/GeneralReport. pdf; Thomas Wachter, «La garantie de crédit transfrontalier sur les immeubles au sein de l'Union européenne - L'Eurohypothèque,» Notarius International, vol. 4, No. 4 (1999): 186; Hans G. Wehrens, "Real Security regarding Immovable Objects - Reflections on a Euro-Mortgage," in Towards a European Civil Code, ed. Arthur Hartkamp, et al. (Haia: Kluwer Law International, 2004), 772; Benedict Foëx, «L'Eurohypothèque,» in L'Européanisation du droit privé: Vers un Code civil européen?, ed. Franz Werro (Fribourg: Editions Universitaires Fribourg Suisse, 1998), 483; J. A. Mouteira Guerreiro, Publicidade e Princípios do Registo, in Temas de Registos e de Notariado (Coimbra: Almedina, 2010), 21; Pascal Ancel, Droit des sûretés (Paris: Éditions Litec, 2000), 130; Otmar Stöcker and Rolf Stürner, Flexibilität, Sicherheit und Effizienz der Grundpfandrechte in Europa (Berlin: Verband Deutscher Pfandbriefbanken, 2012), 35.

${ }^{10} \mathrm{Cfr}$. Council of the Notariats of the European Union, CROBECO Project - Position of the Notaries of Europe (18 Nov. 2011), (Bruxelas2011), 2, http://www.notaries-of-europe.eu/files/positionpapers/2011/Position-CNUE-CROBECO-18-11-11-final-EN.pdf.

${ }^{11}$ Hendrik Ploeger and Bastiaan van Loenen, "EULIS...." 382, and "The European Real Estate Market - Transparency, Security and Certainty through registration by EuroTitle", 187.

${ }^{12}$ Cfr. European Parliament, Comparative Study on Authentic Instruments (Study of the European Parliament n. ${ }^{\circ}$ IP/C/JURI/IC/2008-019 (PE/408329), made by the Council of the Notariats of the European Union, 2008), 144, http://www.cnue-nouvelles.be/en/000/actualites/aae-etude-acteauthentique-final-25-11-2008-en.pdf.

${ }^{13}$ Cf. Jean-François Gojon, "Loi réelle et loi de la créance dans le crédit hypothécaire: un concours encore incertain" in Mélanges en l'Honneur de Mariel Revillard - Liber amicorum (Paris: Defrénois, 2007), 179-180.
} 
CROBECO incorporates an electronic platform connecting Land Registrars of different Member States and a plan of international conveyancing. According to this plan, the parties shall pick a Notary of their choice (probably from the country of habitual residence), who will be glad to accept the choice of law of lex domicilii for contractual obligations ${ }^{14}$ and to draw the contract in the language the parties know best.

This Notary shall benefit from assistance of the local Land Registrar, who will use the CROBECO platform to connect to a Land Registrar from the Member State where the plot of land is and collect data on the requirements of lex rei sitae for the international transaction. Additionally, the local Land Registrar will certify conformity with the local legislation on contractual obligations and issue a certificate on its fulfilment. ${ }^{15}$

In the latest version of CROBECO (CROBECO II), the intervention of the local Land Registrar became optional. Therefore, it implemented the possibility of directly establishing contacts between the local Notary and the Land Registrar from the country where the property is located through an electronic platform (NETPRO), overcoming the criticism on the necessity of intervening two Land Registrars in order to transfer the property. ${ }^{16}$ The NETPRO platform is equipped with several tools optimised to make international conveyancing user-friendly: on the one hand, a repository of typical contract clauses, accepted both by lex contractus and lex rei sitae, ${ }^{17}$ on the other hand, NETPRO incorporates a belpdesk pointing out administrative assistants from the Member State of situation of the property, who will obtain licences, pay taxes and land information and upload all the data in the platform.

Once concluded, the contract (possibly accompanied by the certificate issued by the local Land Registrar) shall be electronically sent to the Member State of situation of the property, where it will be submitted to the Land Registry. ${ }^{18}$

\section{EU-Fides - facilitating real estate transactions in Europe ${ }^{19}$}

Possibly as a reaction to the Registrars initiative, the Council of the Notariats of the European Union (CNUE) presented in September of 2012 a similar project, replacing the mutual aid of Land Registrars by cooperation among civil law notaries

\footnotetext{
${ }^{14}$ Cf. article 3 of EC Regulation 597/2008, on the law applicable to contractual obligations (Rome I).

${ }^{15}$ European Land Registry Association, Common Conveyancing Reference Framework, (2011), 13, http://www.eurogeographics.org/sites/default/files/CommonConveyancingReferenceFramework. pdf: "Although responsibilities never can change, assistance in this field could be provided to Registrars from other Registrars".

${ }^{16}$ Cf. Council of the Notariats of the European Union, CROBECO Project-Position of the Notaries of Europe (18 Nov. 2011), 1: "The cumulative involvement of a notary and two conveyancers is opposed to the genuine idea of facilitating cross-border real estate transaction. In everyday notarial practice, one notary and one registrar sufficed to provide for the services required".

${ }^{17}$ Therefore, a notary (or, if requested, a local Land Registrar) may look up NETPRO platform, selecting in the system lex contractus and lex rei sitae among the laws of Member States. With that information, NETPRO will suggest a certain draw of contractual clauses, observing both applicable laws.

${ }^{18}$ European Land Registry Association, Common Conveyancing Reference Framework, 16 and 42ss.

${ }_{19}$ The Project is described in the internet, via http://www.notaries-of-europe.eu/services/servicesfor-citizens/eufides. On EU-Fides, vide Isidoro Antonio Calvo Vidal, "La Circulación del Documento Público Notarial," in Autonomía de la Voluntad en el Derecho Privado - Estudios en conmemoración del 150 aniversario de la Ley del Notariado, ed. Lorenzo Prats Albentosa (Madrid: Consejo General del Notariado - Wolters Kluwer España, 2013), 84 ss.
} 
from different Member States. The goal is to provide a foreign authentic document containing a contract transferring property with the same effectiveness and certainty of an internal.

In contradistinction to CROBECO, EU-Fides suggests the submission of the contract to lex rei sitae (under Article 3 of Rome I Regulation), promoting a unique applicable law to all aspects of the contract. ${ }^{20}$

EU-Fides organises a list of public notaries of all Member States, publicising the languages spoken - the European Directory of Notaries. ${ }^{21}$ Therefore, the parties shall search for a Notary of the country of the property who can draw the contract in the language preferred (if allowed by lex auctoris) or, at least issue a version of the contract in that language, ${ }^{22}$ and a Notary of their trust - probably in the country of habitual residence. Which means EU-Fides supposes the choice of two notaries: one of the countries of situation of the property and another of the country of the Member State where they wish to conclude the contract. Once the notaries are chosen, EU-Fides starts by the conclusion of a notarial cooperation protocol between the two notaries. This digital protocol will allocate responsibilities and tasks among the two officials. ${ }^{23}$

Afterwards, the Notary of the country where the contract shall be concluded will electronically have digital assistance of the Notary of the country of the property's location, collecting information on the requirements of lex rei sitae for the transaction and benefiting from having an officer who can easily obtain any necessary licences, certificates and fulfil tax obligations. The notary of the country of the property will then issue a "document notification", stating all the steps that must be accomplished for the transaction to be legally effective according to lex situs and sending the necessary documents.

There is, in conclusion, a control of equivalence, since the notary of the Member State of the property verifies the legal requirements for the acceptance, in that country, of a deed, ${ }^{24}$ but also assists in the practical aspects of the contract (paying taxes, accessing to Land Registry, etc.). The notarial specialised advices and duties are,

\footnotetext{
${ }^{20}$ Cf. Ibid. p. 85.

${ }^{21}$ The European Directory of Notaries is available on-line, via www.notaries-directory.eu

${ }^{22}$ In fact, Notarial activity submits to auctor regit actum principle: the law of the country which delegated powers to the notary applies to the possibility of drawing authentic documents in a foreign language Calvo Vidal, "La Circulación del Documento Público Notarial.” 85; Pedro Carrión García de Parada, "Los documentos notariales en los nuevos reglamentos europeos: el Reglamento de sucesiones y la propuesta de Reglamento de régimen económico matrimonial y la de efectos patrimoniales de las parejas registradas," in El documento público extranjero en España y en la Unión Europea. Estudios sobre las características y efectos del documento público, ed. Maria Font i Mas (Barcelona: Bosch, 2014), 219. The auctor regit actum rule was developed by J.-P. Niboyet, «Le conflit des autorités: la règle «auctor regit actum»,» Revue Critique de Droit International Privé, vol. 37 (1948): 398 ("toute autorité publique, habilité à faire certains actes, ne peut jamais les faire selon ses propres lois»), applying not only to courts but to other public authorities, such as "notaire, l'officier de l'état civil, le conservateur des hypothèques» - cfr. François Rigaux and Marc Fallon, Droit International Privé, (Bruxelas: De Boeck \& Larcier, 2005), 104; Pierre Mayer, La distinction entre règles et décisions et le droit international privé, (Paris: Dalloz, 1973), 132; Adolfo Miaja de la Muela, Derecho Internacional Privado, in Introduccion y Parte General (Madrid: Atlas, 1976), 19; J.-P. Niboyet, Manuel de Droit International Privé (Paris: Recueil Sirey, 1928), 864.

${ }^{23}$ CNUE publishes models of protocols, with example clauses to be decided by both notaries.

${ }^{24}$ Cf. Barbara Pasa, "La propuesta de reglamento sobre libre circulación de los 'documentos públicos' en la Unión Europea y el notariado latino," in El documento público extranjero en España y en la Unión Europea. Estudios sobre las características y efectos del documento público, ed. Maria Font i Mas (Barcelona: Bosch, 2014), 181.
} 
therefore, shared: the local official shall verify all aspects concerning the parties (e. g., capacity and legitimacy); the official of the country of the property shall assess the requirements of the transaction according to lex situs. EU-Fides thus acknowledges international conveyancing is easier when there is an official of the Member State of the property. ${ }^{25}$

The drawing of the deed (only one deed) is committed to the Notary of the country of the parties, fulfilling the solemnities of that law (auctor regit actum), and mentioning additional data possibly demanded by lex situs (e. g., payment method; registration requirements; notices on the intervention of real estate mediators). Notwithstanding, the deed benefits from the knowledge and expertise of two Notaries: consequently, it will be digitally signed by both Notaries. ${ }^{26}$ If the Member State of the situation of the property does not accept foreign deeds (like the Netherlands), EU-Fides provides for the drawing of a "clausula de apoderamiento que faculte al notario nacional para llevar a cabo todas aquellas actuaciones que, siento complementarias, resulten precisas en el Estado de destino de acuerdo con el proprio ordenamiento". ${ }^{27}$

Once the digital deed is drawn, the Notary of the country of the property takes responsibility for the remaining process, being responsible for requesting Land Registry acts, payment of taxes, notification to public authorities or any other duties established by lex rei sitae.

\section{IMOLA - Interoperability Model for Land Registers ${ }^{28}$}

The issue addressed by ELRA (European Land Registry Association) in the IMOLA project was the effective access to Land Registry information within the $\mathrm{EU}$ as a result of the problems dealt before (specially the differences in national legislation, divergences inherent to the practice of land registration and the fact of registries being encoded in different formats only accessed through proprietary and non-standard protocols).

Therefore, IMOLA aims at building a standard means of accessing basic Land Registry information within the EU, paired with explanatory material of foreign legal systems. After performing research on the common points of each national system, the Project aims at providing interoperability solutions through a model for standardised Land Registry output: the European Land Registry Document (ELRD). The ELRD formulates reference information within a structure of common fields (Template), developed through an XSD/XML scheme that allows semi-automatic processing of information through shared rules with metadata derived from a thesaurus.

In the latest version of the project (IMOLA II) - after the development of the ELRD -, the goal is to provide an interoperability platform among Land Registers in Europe, through the e-Justice Portal and linked directly to the semantic domain represented by IMOLA controlled vocabularies, glossaries and thesauruses.

\footnotetext{
${ }^{25}$ Cfr. Calvo Vidal, “La Circulación del Documento Público Notarial.”, 91.

26 José Rodríguez Calvo, "Las transacciones inmobiliarias en España realizadas por extranjeros," in El documento público extranjero en España y en la Unión Europea. Estudios sobre las características y efectos del documento público, ed. Maria Font i Mas (Barcelona: Bosch, 2014), 395.

${ }^{27}$ Calvo Vidal, "La Circulación del Documento Público Notarial", 94; Rodríguez Calvo, "Las transacciones inmobiliarias en España realizadas por extranjeros.”, 397. Editor's note: clause of empowerment that empowers the national notary to carry out all those actions that, being complementary, are accurate in the State of destination in accordance with the proper order.

${ }^{28}$ The Project is described in the internet, via https://www.elra.eu/imola-ii/.
} 
The approach followed by IMOLA is, thus, different from the above: instead of creating mechanisms of enhancing cooperation between officials of different Member States through e-Justice tools, IMOLA aims to build a digital unification of Land Registry Information, allowing a Notary or a Land Registrar of a certain Member State to access the necessary data abroad.

\section{Conclusions}

It is clear none of the analysed projects is enough to solve all the problems concerning international conveyancing within the European Union. It is obvious these e-Justice solutions are not enough to overcome all difficulties and, on the other hand, rectify several deficiencies. ${ }^{29}$

However, the existence of these projects shows that there is a tendency of solving the difficulties of international cooperation between non-judicial authorities through e-Justice tools. Which means e-Justice mechanisms are being enhanced not only within the civil cooperation between courts but also among other authorities whose intervention is designed to avoid litigation - such as Notaries and Registrars.

\footnotetext{
${ }^{29}$ For a critical approach to these solutions, cfr. Patrão, Autonomia Conflitual... 668ff.
} 